\title{
The Janus-Face of Ius Sanguinis: Protecting Migrant Children and Expanding Ethnic Nations
}

\author{
Francesca Decimo
}

Costica Dumbrava's proposal for abandoning ius sanguinis is timely and bold. My intuition is to reject his suggestion that children's citizenship might be disconnected from that of their parents, but to join his advocacy for a radical rethinking of the ius sanguinis principle with a view towards eliminating it once and for all. These are rather contrasting stances in relation to the same principle. Let us see if the apparent contradiction can be resolved.

To begin, let us consider the element of Costica Dumbrava's proposal that has elicited most attention and controversy among the respondents, but was picked up and expanded by Lois Harder, namely the assertion that granting citizenship at birth is unnecessary and, above all, that making children dependent on the legal status of their parents exposes them to a form of vulnerability. The idea of postponing the acquisition of citizenship until adulthood, taking into account birthplace and residence or possession of the appropriate attitudes and skills, derives from the classic opposition between ius sanguinis and ius soli according to which the former is considered ethnic and exclusive while the latter is considered civic and inclusive. Yet Rainer Bauböck's comments on this point explain how, in the absence of parental transmission of citizenship to children, ius soli and ius domicilii can generate individual and familial conditions that are both legally paradoxical and morally unfair.

I share the doubts and critiques raised by Rainer Bauböck, Scott Titshaw and Kristin Collins regarding the alleged emancipatory value of a citizenship system that disconnects children from their parents. Particularly, I consider any legal system that fails to specifically protect the relationship between parents and children to be highly risky. Indeed, who should children depend on if not their parents? Dumbrava's proposal that children might instead be subject to, and protected by, a kind of international law faces the problem of subordinating the individual and familial reproductive spheres to institutional logics. 
As Luc Boltanski has noted, ${ }^{1}$ the event of birth is inextricably linked to the definition of belonging and social descent - and therefore legal, political, cultural, national, etc. descent as well. Historically, devices for legitimating the procreative event were provided by religion, ancestry, the nation-state and, in more recent times, a long-term relationship among a couple. In a scenario in which parentage and citizenship are not tightly connected from the beginning, the risk is not only that of generating stateless children but also an excess of state power. Even after World War Two, the Catholic Church in Ireland took children considered illegitimate away from their unmarried mothers. It was nationalist demographic policies, both in Europe and overseas, that shaped the reproductive choices of individuals and families during the 20th century with a view to producing children for the fatherland. We might recall these policies when interpreting some recent nationally-oriented arguments encouraging the children of immigrants to rid themselves of the burden of their cultures of origin in which their inadequately assimilated mothers and fathers remain stuck. ${ }^{2}$ With this in mind, do we really want to define children's citizenship irrespective of their parents'? Do we really want to shift the task of determining the legitimate membership of our offspring from relationships to institutions?

The considerations made thus far therefore lead me to agree with those who have argued that, as long as the system of nation-states regulates our rule of law, children's citizenship must be linked from birth to that of their parents.

At the same time, it seems to me that ius sanguinis is a legal instrument which, especially in a global context of increased geographical mobility, opens the way to policies of attributing nationality that go far beyond protecting the parent-child relationship. This point relates to Dumbrava's observation that ius sanguinis is historically tainted that was critically addressed by Jannis Panagiotidis but has not yet been decisively refuted.

As scholars have noted, ius sanguinis makes it possible to recognise a community of descendants as legitimate members of the nation regardless of its territorial limits, but that is not all. This principle has been used to grant the status of co-national to individuals dispersed not only across space but also across time, leading to the construction of virtually inexhaustible intergenerational chains. ${ }^{3}$ This principle is based on blood, identified as the

See Boltanski, L. (2004), La condition foetale. Paris: Gallimard.

See Hungtinton, S. (2004), Who are we? New York: Simon and Schuster.

3 See: Brubaker, R. (1992), Citizenship and Nationhood in France and

Germany. Cambridge: Harvard University Press. 
essential and primordial element of descent, belonging and identification. It is true that this potential for unlimited intergenerational transmissibility is effectively defused by the fact that many countries interpret ius sanguinis narrowly, applying it generally only up to the second generation born abroad. And yet, is this limit enough to bind and delimit the potential of ius sanguinis? In national rhetoric the image of a community of descendants continues to exert a powerful appeal that goes beyond the attribution of birthright citizenship. In historical emigration countries - but also others $-{ }^{4}$ ius sanguinis as a legal practice is used to grant preferential conditions and benefits to descendants as part of the direct transmission or 'recovery' of ancestral citizenship well beyond the second generation. ${ }^{5}$ Generational limits in the granting of citizenship to descendants can thus be bypassed because, in principle, ius sanguinis itself poses no particular restrictions in this regard.

The most controversial aspects of ius sanguinis emerge when this principle ends up competing with ius soli or ius domicilii, that is, when individuals born and raised elsewhere enjoy a right to citizenship in the name of lineage and an assertion of national affiliation while immigrants who participate fully in the economic, social and cultural development of the country are denied this same right or face serious obstacles in accessing it. In such context - Germany in the past and Italy today - the right to citizenship effectively becomes a resource which, like economic, human and social capital, is distributed in a highly unequal way, benefitting certain categories of people - 'descendants' - at the expense of others - 'foreigners'.

In view of its unlimited intergenerational potential, I conclude that, if its purpose is merely to bind children's citizenship to that of their parents, ius sanguinis as a legal instrument suffers from ambiguity and disproportionality. All of these critical points seem to be implicitly overcome in Bauböck's proposal of a ius filiationis principle, which would focus entirely on linking children's citizenship to that of their parents, especially for migrants and non-biological offspring. Under a different name and with distinct content,

4 Joppke's comparison of three highly divergent countries, France, Italy and Hungary, is quite effective in shedding light on this issue in Joppke, C. (2005), Selecting by Origin. Cambridge: Harvard University Press, 240-250.

5 For an in-depth analysis of the Italian case, see Decimo, F. (2015). Nation and reproduction: Immigrants and their children in the population discourse in Italy. Nations and Nationalism, 21(1), 139-161; Tintori, G. (2013), Naturalisation Procedures for Immigrants. Florence: European University Institute Robert Schuman Centre for Advanced Studies, EUDO Citizenship Observatory, available at http://cadmus.eui.eu/bitstream/handle/1814/29787/ NPR_2013_13-Italy.pdf?sequence $=1$ 
does this move not suggest that, rather than modifying or modernising ius sanguinis as advocated by Rainer Bauböck and Scott Titshaw, it is time to abandon it once and for all, adopting in its place a principle that explicitly protects parentage and citizenship in contexts of geographical mobility instead of linking it to genealogical lineage and nationhood?

Open Access This chapter is licensed under the terms of the Creative Commons Attribution 4.0 International License (http://creativecommons.org/licenses/by/4.0/), which permits use, sharing, adaptation, distribution and reproduction in any medium or format, as long as you give appropriate credit to the original author(s) and the source, provide a link to the Creative Commons license and indicate if changes were made.

The images or other third party material in this chapter are included in the chapter's Creative Commons license, unless indicated otherwise in a credit line to the material. If material is not included in the chapter's Creative Commons license and your intended use is not permitted by statutory regulation or exceeds the permitted use, you will need to obtain permission directly from the copyright holder.

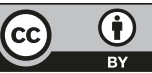

